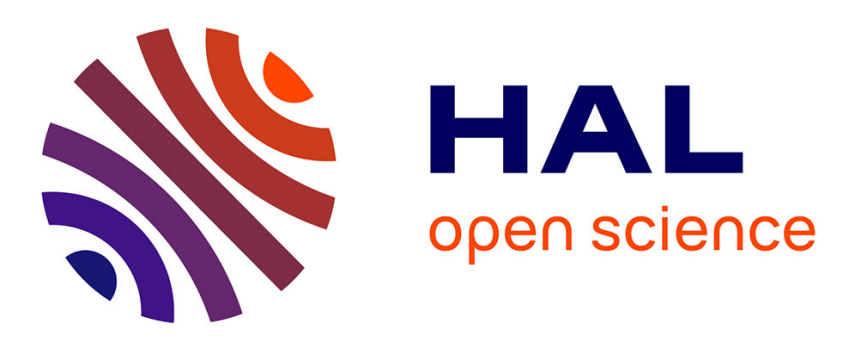

\title{
Robustness analysis and Evaluation of a PMSG-based Marine Current Turbine System under Faulty Conditions
}

\author{
Sana Toumi, Seifeddine Benelghali, Mohamed Trabelsi, El Houssin El \\ Bouchikhi, Mohamed Benbouzid, Mohamed Faouzi Mimouni
}

\section{To cite this version:}

Sana Toumi, Seifeddine Benelghali, Mohamed Trabelsi, El Houssin El Bouchikhi, Mohamed Benbouzid, et al.. Robustness analysis and Evaluation of a PMSG-based Marine Current Turbine System under Faulty Conditions. Proceedings of the IEEE STA 2014, Dec 2014, Hammamet, Tunisia. pp.631636. hal-01122813

\section{HAL Id: hal-01122813 https://hal.science/hal-01122813}

Submitted on 4 Mar 2015

HAL is a multi-disciplinary open access archive for the deposit and dissemination of scientific research documents, whether they are published or not. The documents may come from teaching and research institutions in France or abroad, or from public or private research centers.
L'archive ouverte pluridisciplinaire HAL, est destinée au dépôt et à la diffusion de documents scientifiques de niveau recherche, publiés ou non, émanant des établissements d'enseignement et de recherche français ou étrangers, des laboratoires publics ou privés. 


\title{
Robustness analysis and Evaluation of a PMSG-based Marine Current Turbine System under Faulty Conditions
}

\author{
S. Toumi, S.E. Ben Elghali, M. Trabelsi, E. Elbouchikhi, M.E.H. Benbouzid, M.F. Mimouni
}

\begin{abstract}
This paper deals with a Permanent Magnet Synchronous Generator (PMSG) driven by a Marine Current Turbine (MCT) through a PWM power rectifier and used for isolated sites. The generator model is established in the synchronous rotating $d q$ reference frame. The control of the speed, the $d$-axis current, and the $q$-axis current is achieved using PI correctors. Robustness and performance of the considered system are evaluated in healthy and faulty conditions. The faulty mode deals with the study of single and multiple openswitch damages appearing in the PWM power rectifier. Simulations are carried-out to highlight the proposed PMSG-based MCT performance in both cases.
\end{abstract}

Index terms-Marine current turbine, permanent magnet synchronous generator, PWM power rectifier, MPPT, control, open-circuit faults.

\section{NOMENCLATURE}

$\begin{array}{rll}\text { MCT } & = & \text { Marine Current Turbine; } \\ \text { PMSG } & = & \text { Permanent Magnet Synchronous Generator; } \\ \text { MPPT } & = & \text { Maximum Power Point Tracking; } \\ \text { IGBT } & = & \text { Insulated Gate Bipolar Transistor; } \\ \text { PWM } & = & \text { Pulse Width Modulation; } \\ P_{m} & = & \text { Mechanic power; } \\ C_{p} & = & \text { Power coefficient; } \\ \lambda & = & \text { Tip speed ratio; } \\ \beta & = & \text { Blade pitch angle; } \\ \rho & = & \text { Fluid density; } \\ r & = & \text { Turbine radius; } \\ v_{t} & = & \text { Tidal speed; } \\ R & = & \text { Resistance. }\end{array}$

S. Toumi, M. Trabelsi, M.F. Mimouni: Unité de recherché Etude des systems industriels et des energies renouvelables (ESIER), Ecole nationale d'ingenieurs de Monastir (ENIM), Rue Ibn El JazzarMonastir-5000, (e-mail : sanaatoumii@gmail.com, Medtrabelsi@yahoo.fr, Mfaouzi.mimouni@enim.rnu.tn )

S.E. Ben Elghali: Laboratoire des Sciences de l'Information et des Systèmes (LSIS)- UMR CNRS 7296Avenue Escadrille Normandie Niemen 13397 Marseilles Cedex 20- France (e-mail: seifeddine.benelghali@1sis.org )

E. Elbouchikhi: ISEN Brest, EA 4325 LBMS, 20, Rue Cuirassé Bretagne, $29200 \quad$ Brest, France (e-mail: ELhoussin.Elbouchikhi@isen.fr )

M.E.H. Benbouzid: Université de Brest, EA 4325 LBMS, Rue de Kergoat - CS 93837, 29238 Brest, France (e-mail: Mohamed.Benbouzid@univ-brest.fr)

\section{INTRODUCTION}

Because of oceans cover more than $70 \%$ of the earth, many new renewable energy sectors are emerging and interesting development are taking place such as thermal energy, wave energy and marine tidal energy [1]. Indeed, the potential of electric power generation from marine tidal currents is very interesting; it has been shown that $48 \%$ of the European tidal resource in the UK, $42 \%$ in France and $8 \%$ in Ireland [2] [3].

Unfortunately, in the literature there is no study about defaults in the hydraulic conversion chain. But, certainly, hydrodynamic energy conversion systems are exposed to environmental and functional constraints. Firstly, environmental constraints are due to the severe weather conditions because of the geographic location (installation under the sea and existence of harmonic current speeds caused by the swell and wave), second, functional constraints are due to the increase in power implies to a higher voltages and / or currents transited. These constraints provide the degradation of performance of the various functional blocks of the system and its accelerated aging process, which leading to many faults essentially related to the blades, to the PMSG (short-circuit between turns, between phases and between phase and neutral) and even to the rectifier (short-circuit faults, open-circuit faults and intermittent gate misfiring faults).

This paper describes the hydrodynamic conversion system by giving the modeling of each component: the MCT, the PMSG and the PWM power rectifier. The control of this chain is achieved by using: MPPT control for extracting of the maximum power and proportional integral correctors to control the speed and the $d q$-axis currents. Besides, we are focus on the impact of an open-circuit fault in the PWM power rectifier.

This paper is structured as follows; in section II, the hydrodynamic conversion chain structure is given. In section III, the models of the marine current turbine and the PMSG are developed. In section IV, control of the system will be presented. In section $\mathrm{V}$, performance evaluation results are presented. The conclusion is given in section VI.

\section{HYDRODYNAMIC CONVERSION CHAIN STRUCTURE}

As shown in fig. 1, the conversion chain is composed by marine turbine, a permanent magnet synchronous machine coupled to a DC Bus through a PWM power rectifier. 


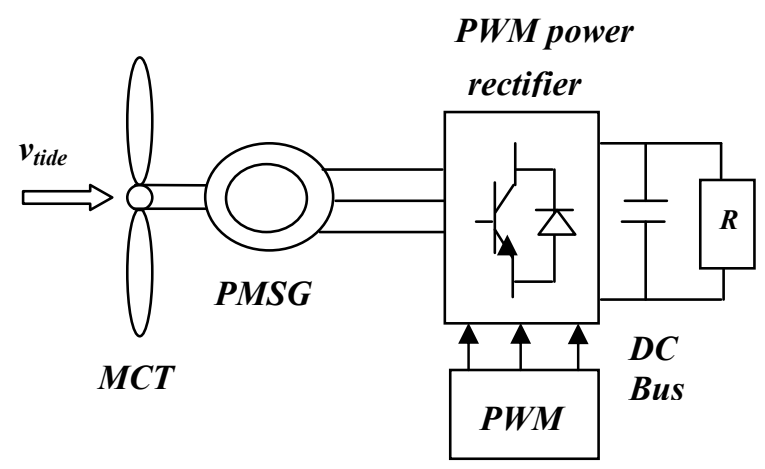

Fig. 1. General scheme for a hydraulic conversion chain in isolated site

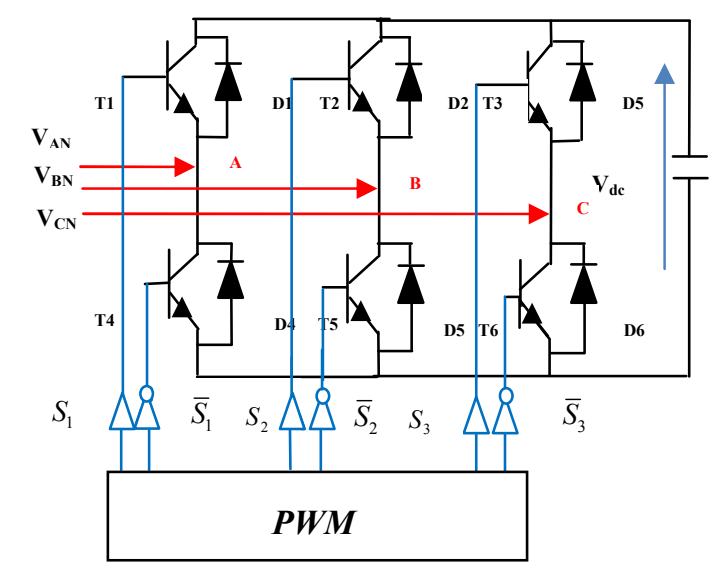

Fig. 2. PWM power rectifier topology

Fig. 2 presented the PWM power rectifier, this converter uses the three-phase voltage sources provided by the PMSG. It composed by a three legs, each leg features two semiconductor switches $\left(T_{k}, T_{k+3}\right.$ $\mathrm{k}=1,2$, 3) with antiparallel connected freewheeling diodes $\left(D_{k}, D_{k+3}\right)$. The switches of the same leg are controlled by a PWM bloc in the form of a logic control signals $S_{k}(k=1,2,3)$ also known gate signals, it defined by:

$$
\mathrm{S}_{k}=\left\{\begin{array}{lll}
1 & \text { if } \mathrm{T}_{\mathrm{k}} \text { on and } & \mathrm{T}_{\mathrm{k}+3} \text { off } \\
0 & \text { if } \mathrm{T}_{\mathrm{k}+3} \text { on and } & \mathrm{T}_{\mathrm{k}} \text { off }
\end{array}\right.
$$

\section{ENERGY CONVERSION SYSTEM MODELING}

\section{A. Marine current turbine modeling}

The mechanic power for a marine current turbine has a similar dependence to that of a wind turbine and is given by the following equation [4] [5]:

$$
P_{m}=\frac{1}{2} C_{p}(\lambda, \beta) \rho \pi r^{2} v_{t}^{3}
$$

$\mathrm{C}_{\mathrm{p}}$ presents the percentage of mechanical power that can be extracted from the fluid stream by the turbine.

For typical MCTs, the optimal $\mathrm{C}_{\mathrm{p}}$ value for normal operation is estimated to be in the range of
$0.35-0.5$ [6]. Indeed, basing on the experimental results and for a given turbine, the $\mathrm{C}_{\mathrm{p}}$ can be approximated as a function of the tip speed ratio $\lambda$ and the blade pitch angle $\beta$ [7].

Fig. 3 illustrates the $C_{p}$ curve for simulations.

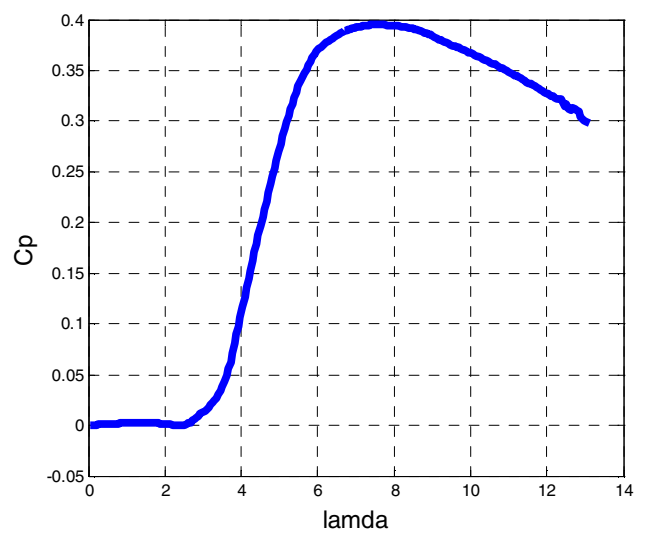

Fig. 3. Power Coefficient curve $\mathrm{Cp}$

\section{B. Marine current generator modeling}

The generator chosen for the marine current system was the PMSG [8], it has be chosen because of its advantages such as high efficiency, compact structure and the possibility to eliminate the gearbox that reduce the maintenance and this very favorable in terms of underwater application [9].

Dynamic modeling of PMSG can be described in $\mathrm{d}-\mathrm{q}$ reference system as follows [10] [11] [12]:

$$
\left\{\begin{array}{l}
\frac{d i_{s d}}{d t}=-\frac{R_{s}}{l_{s}} i_{s d}+p \Omega i_{s q}+\frac{v_{s d}}{l_{s}} \\
\frac{d i_{s q}}{d t}=-\frac{R_{s}}{l_{s}} i_{s q}-p \Omega i_{s d}-\frac{p \Phi_{a}}{l_{s}} \Omega+\frac{v_{s q}}{l_{s}} \\
\frac{d w}{d t}=\frac{p}{J_{t}} T_{m}-\frac{p}{J_{t}} T_{e m}-\frac{p}{J_{t}} f \Omega \\
T_{e m}=\frac{3}{2} p \Phi_{a} i_{s q}
\end{array}\right.
$$

\section{ENERGY CONVERSION SYSTEM CONTROL}

Fig. 4 shows the control scheme for the energy conversion chain. 


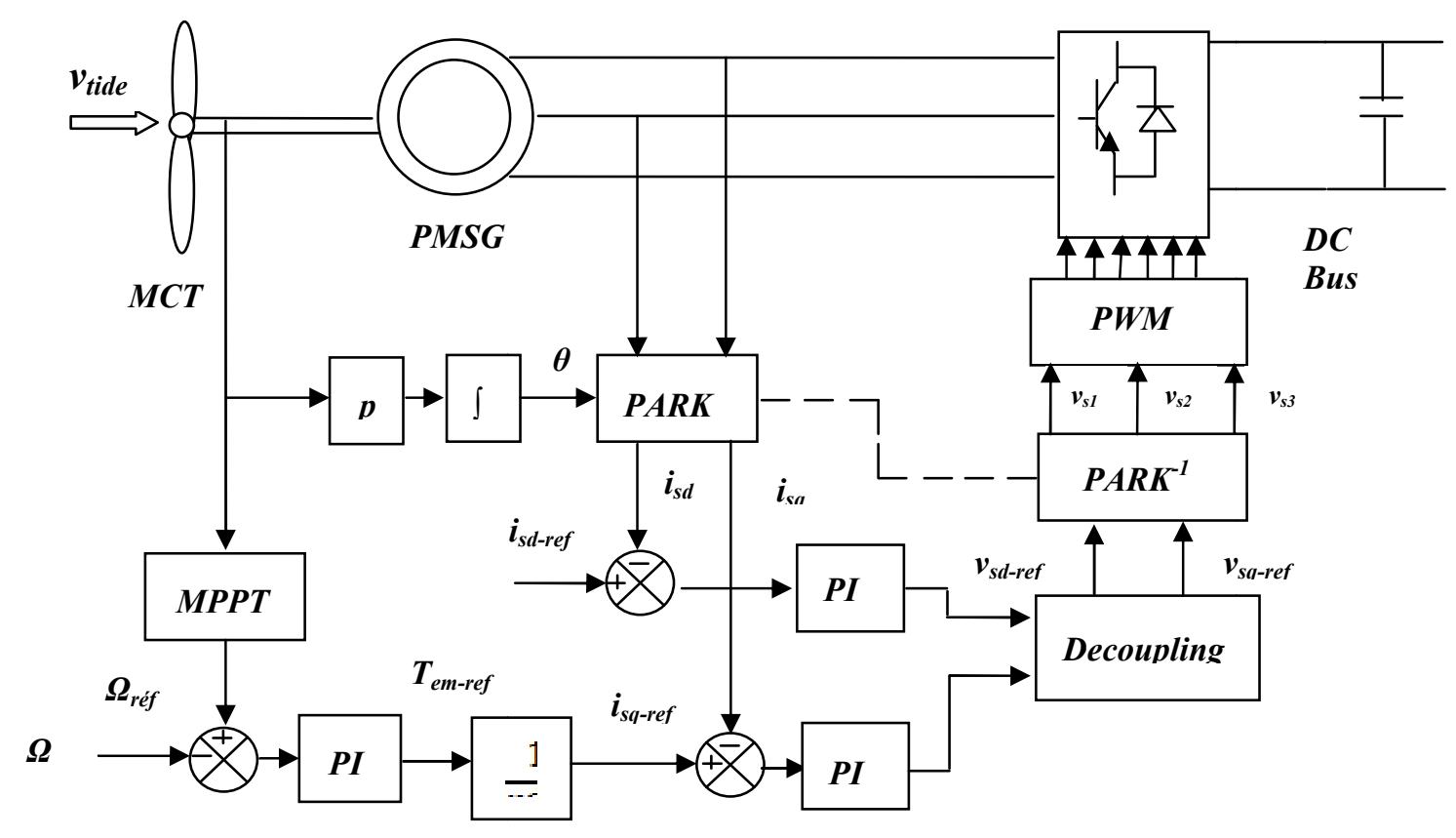

Fig. 4. Control scheme of energy conversion chain

Firstly, MPPT technique consists in controlling the rotor speed to keep the turbine tip ratio $\lambda$ at its optimal value, thus keeping the turbine power coefficient $\mathrm{C}_{\mathrm{p}}$ at the maximum value, which leads to achieve the expected power extracted by the MCT.

The expression of the turbine speed reference calculated by the conventional MPPT is given by:

$$
\Omega_{r e f}=\frac{v_{m} \lambda_{o p t}}{r}
$$

Then, a classical speed control of the generator ensures the convergences of the rotor speed to $\Omega_{\text {ref }}$ based on PI control.

The d-axis current reference is set to zero to minimize resistive losses and therefore minimize current for a given torque, so, we can control the generator torque directly by the quadrature current component [13]. The q-axis current reference is calculated by the speed loop controller.

The required $d-q$ components of the rectifier voltage vector are derived from two PI currents controllers. Then, we added the compensation terms to improve the dynamic response [14] [15].

Finally, PWM is used to generate the control signal to implement the vector control for the generator.

\section{PERFORMANCE EVALUATION RESULTS}

\section{A. Simulation parameters}

Tidal currents are proven by the effect of the moon. Indeed, the moon gravitational pull forces the ocean to bulge outwards on opposite sides of the earth, which causes a rise in the water level in places that are aligned with the moon and a decrease in water levels halfway between those two places. This rise in water level is accompanied by a horizontal movement of water called the tidal current.

Fig. 5 shows the simulation curve of marine current speed.

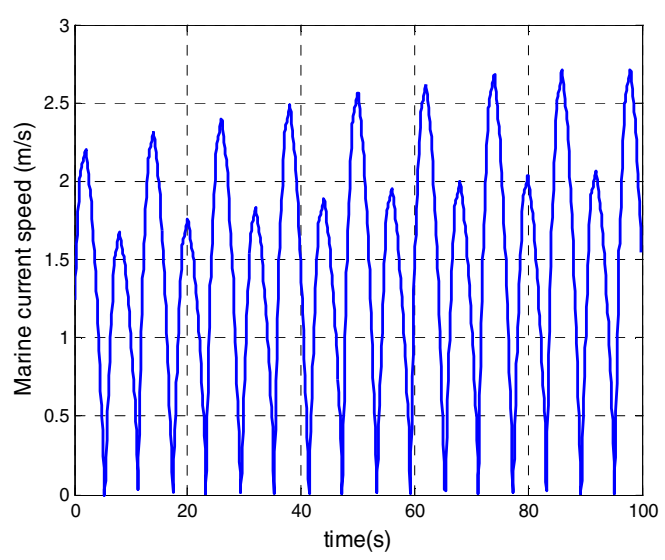

Fig. 5. Marine current speed 
TABLE I. SYSTEM PARAMTER LIST

\begin{tabular}{|c|c|}
\hline \multicolumn{2}{|c|}{ MCT PARAMATER } \\
\hline Turbine blade radius & $0.87 \mathrm{~m}$ \\
\hline Number of blades & 3 \\
\hline Fluid density & $1027.68 \mathrm{Kg} / \mathrm{m}^{3}$ \\
\hline \multicolumn{2}{|c|}{ PMSG PARAMETER } \\
\hline Generator stator resistance & $0.173 \mathrm{~m} \Omega$ \\
\hline Generator d-axis reference & $0.085 \mathrm{mH}$ \\
\hline Generator q-axis reference & $0.951 \mathrm{mH}$ \\
\hline Permanent magnet flux & $0.112 \mathrm{~Wb}$ \\
\hline Generator inertia & $0.0048 \mathrm{~kg} . \mathrm{m}^{2}$ \\
\hline Viscosity coefficient & $8.510^{-3} \mathrm{Nm} / \mathrm{s}$ \\
\hline PWM POWER RECTIFIER \\
\hline Turn-On time & $0.13 \mu \mathrm{s}$ \\
\hline Turn-Off time & $0.445 \mu \mathrm{s}$ \\
\hline Dead time & $4 \mu \mathrm{s}$ \\
\hline Duty-cycle frequency & $5 \mathrm{kHz}$ \\
\hline DC-bus voltage & $600 \mathrm{~V}$ \\
\hline
\end{tabular}

\section{B. Considered faults}

Although IGBTs are rugged, they suffer failure due to excess thermal and electrical stress, these failures can be broadly categorized as short-circuit faults, open-circuit faults and intermittent gate misfiring faults. Indeed, IGBT's open-circuit faults are usually linked to the loss of bonding wires of the control signal or to a short-circuit fault causing rupture of the transistor [16] [17]. Also, this fault can arise when the switches are destructed by an accidental over current or a fuse connected with series for short protection is blown out [18]. Because of the opencircuit faults, the converter cannot synthesize desired output voltages and it provides a large torque ripple, an increased harmonic component in current [19].

In this section, we will consider an open circuit of the upper switch, the lower switch and the two switches on the same time of the first PWM power rectifier leg and we will consist in studying the influence of this fault on the PMSG phase currents.

Fig. 6 shows the three case of an open circuit.

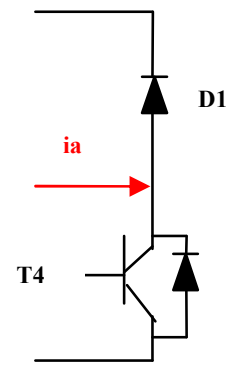

(a)

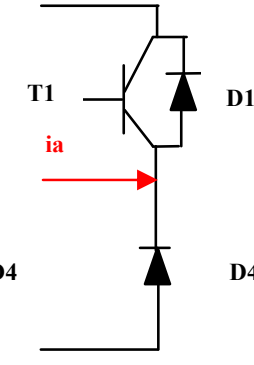

(b)

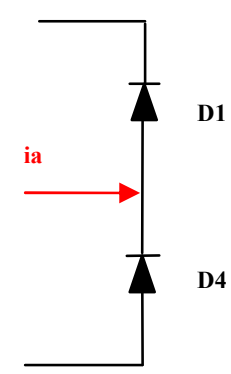

(c)
Fig. 6. (a) An open circuit of the upper switch (T1), (b) An open circuit of the lower switch (T4), (c) A simultaneous open-switches (T1 and T4)

\section{Simulation results}

In this section, a simulation software has been set up by using the Matlab/Simulink/SimPowerSystem environment.

The parameters used in simulation tests are displayed in Table I.

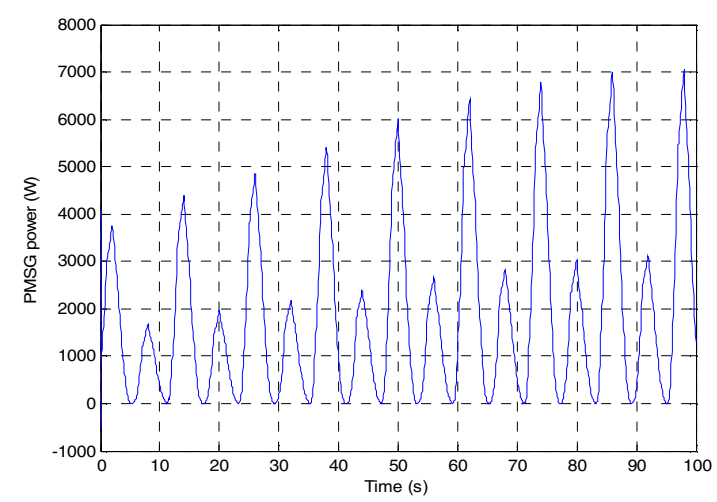

Fig. 7. PMSG power

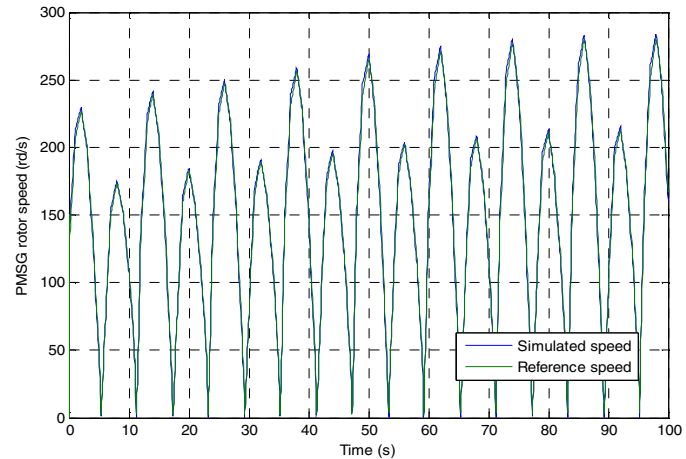

Fig. 8. PMSG speed and its reference

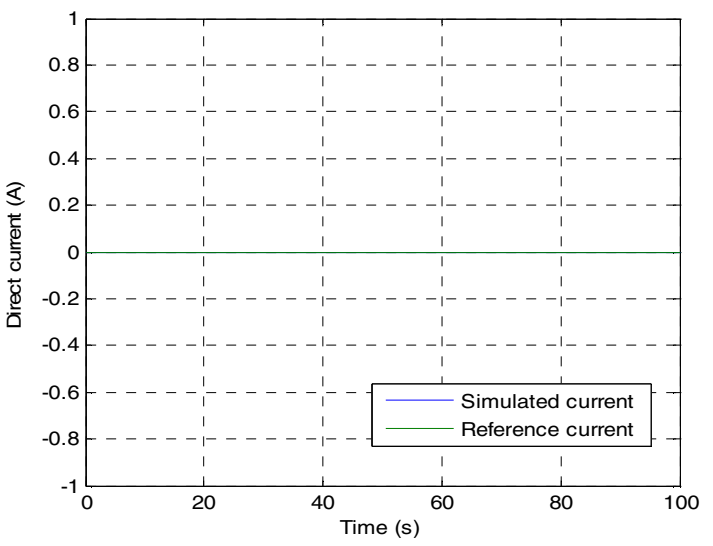

Fig. 9. Direct current and its reference 


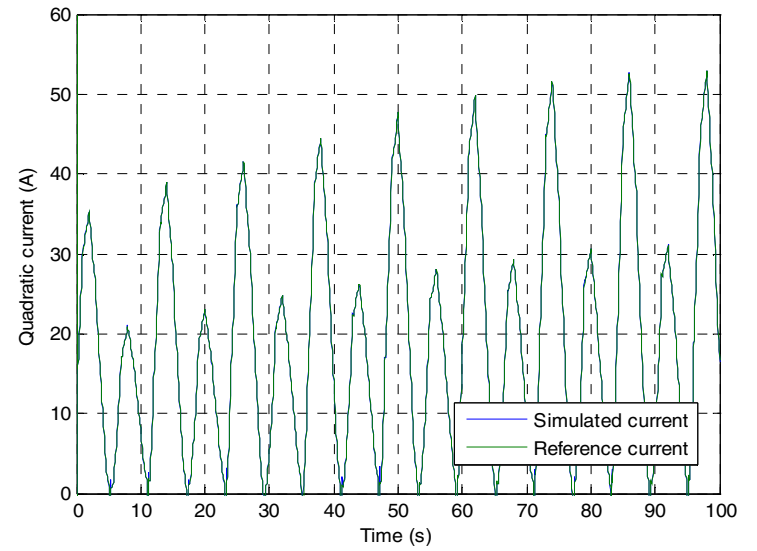

Fig. 10. Quadratic current and its reference

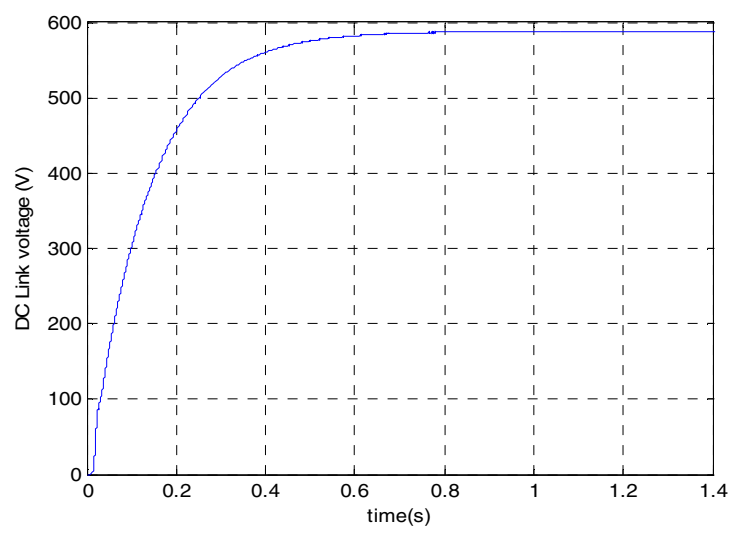

Fig. 11. DC link voltage

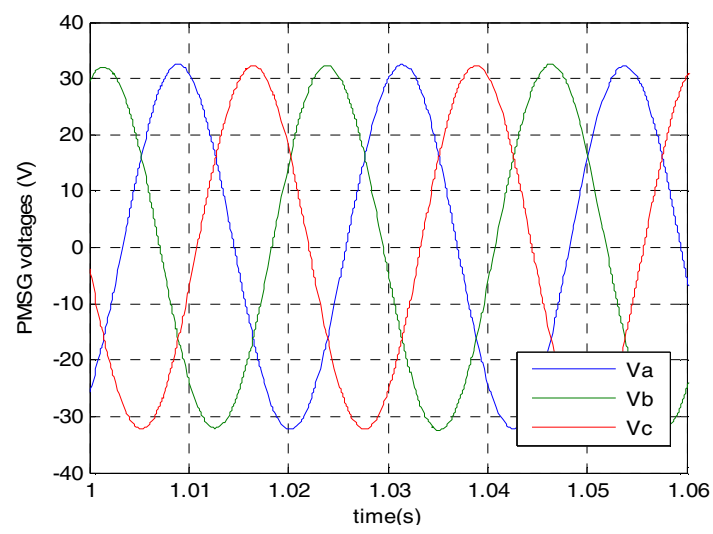

Fig. 12. PMSG voltages Vabc

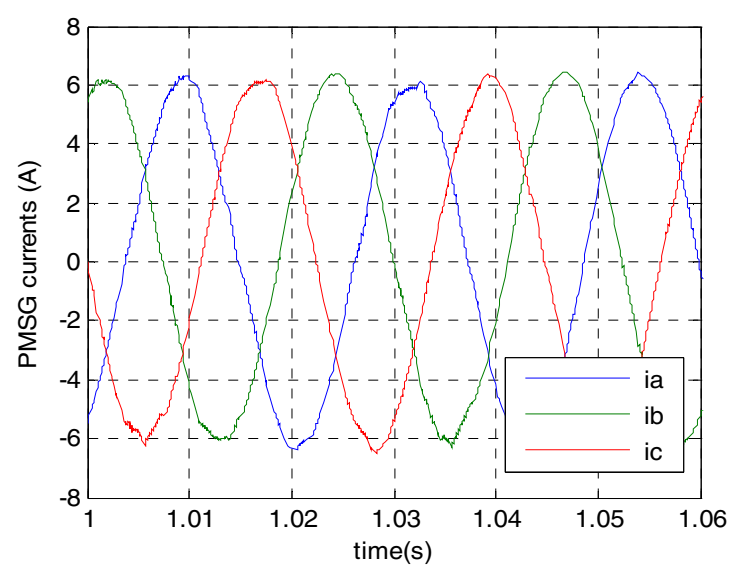

Fig. 13. PMSG currents iabc

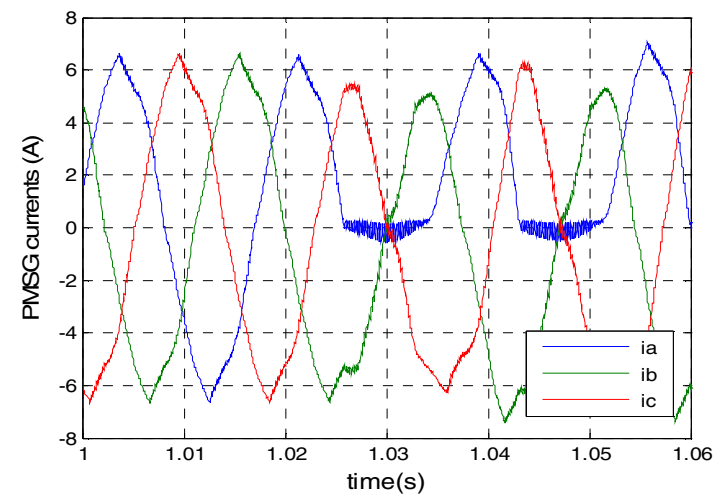

Fig. 14. PMSG currents iabc after an open-circuit fault in the upper transistor $\mathrm{T} 1$

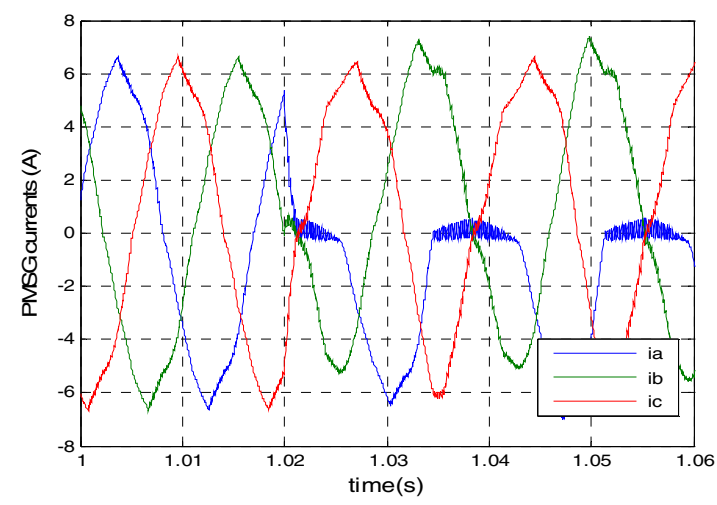

Fig. 15. PMSG currents iabc after an open-circuit fault in the lower transistor T4

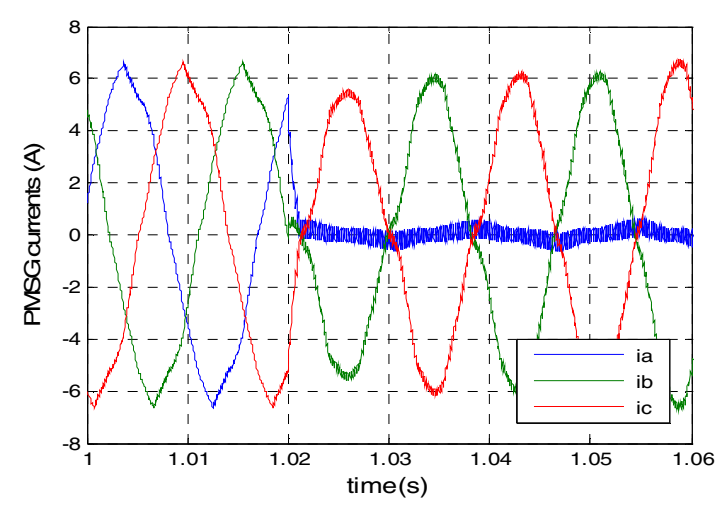

Fig. 16. PMSG currents iabc after a simultaneous openswitches (T1 and T4)

The PMSG power (fig. 7) and the PMSG speed (fig. 8) are deeply correlated with the current marine speed (fig. 5).

The direct current is maintained to zero (fig. 9), the quadratic current (fig. 10) and The PMSG rotor speed (fig.8) are maintained to theirs references. Thus proves the effectiveness of the established regulators.

Fig. 11 shows that the DC bus voltage is constant.

The PMSG voltages and currents are given by fig. 12 and fig. 13; they are three sinusoidal voltages and currents with constant frequency equal to $50 \mathrm{~Hz}$. 
Under normal operating conditions and for faulty states, the PWM power rectifier has been modeled with a real model of the power switches and the by-pass diodes. A dead time of $4 \mu \mathrm{s}$ has introduced to prevent short-circuits within the rectifier legs. A fault condition is caused at $t=1.02 \mathrm{~s}$. In fig. 14 , the fault is applied to the upper switch (T1), it is observed that the phase current $i_{a}$ lost its negative direction and it is flowing only in a positive direction but in fig. 15, where the fault is applied to the lower switch (T4), we show the opposite result because in this case the phase current $i_{a}$ lost its positive direction and conserve only its negative direction. In fig. 16, where we applied a multiple opencircuit fault for the upper switch (T1) and the lower switch (T4), the phase current $i_{a}$ drops to zero.

\section{CONCLUSION}

This paper presents the modeling and the control of an energy conversion chain in isolated site based on a permanent magnet synchronous generator. We have used the $\mathrm{d}-\mathrm{q}$ rotor reference to model overall the system. The main focus has been the study of the performance of the considered system in healthy and faulty conditions such as an open-circuit fault of a single and a multiple switch in the PWM power rectifier and its influence on the three phase currents. The proposed system has been performed by using Matlab/Simulink.

\section{REFERENCES}

[1] S.E. Ben Elghali, M.E.H. Benbouzid and J.F. Charpentier, "Marine tidal current electric power generation technology: State of the art and current status," in Proceedings of IEEE IEMDC'07, Antalya (Turkey), vol. 2, pp. 1407-1412, May 2007

[2] S.E. Ben Elghali, M.E.H. Benbouzid and J.F. Charpentier, "Modeling and control of a marine current turbine driven doubly-fed induction genrator," IET Renewable Power Generation, vol. $4, n^{\circ} 1$, pp. 1-11, January 2010

[3] S.E. Ben Elghali, M.E.H. Benbouzid, T. Ahmed-Ali and J.F. Charpentier, "High-order sliding mode control of a marine current turbine driven doubly-fed induction generator," IEEE Journal of Oceanic Engineering, June 2010.

[4] A.S. Bahaj et al., "Fundamentals applicable to the utilisation of marine current turbines for energy production," Renewable Energy, vol. 28, pp. 2205-2211, 2003.

[5] J.S. Couch et al., "Tidal current energy extraction: Hydrodynamic resource characteristics," Proc. IMechE, Part M: Journal of Engineering for the Maritime, vol. 220 , n'4, pp. 185-194, 2006.

[6] S.E. Ben Elghali, R. Balme, K. Le Saux, M.E.H Benbouzid, J.F. Charpentier and F. Hauville, " A simulation model for the evaluation of the electrical power potential harnessed by a marine current turbine," IEEE Journal on Oceanic Engineering, vol. 32, n 4 , pp. 786-797, October 2007.

[7] J.G. Slootweg, S.W.H de Haan, H. Polinder and W.L. Kling, "General model for representing variable speed wind turbines in power system dynamics simulations," IEEE Trans. Power Systems, vol. 18, n 1 , pp.144-151, February 2003.

[8] J.F. Conroy et al., "Frequency response capability of full converter wind turbine generators in comparison to conventional generation," IEEE Trans. Power Systems, vol. 23, n², pp. 649-656; May 2008

[9] Z. Zhou, F. Scuiller, J.F. Charpentier, M.E.H. Benbouzid and T. Tang, "Grid-connected marine current generation system power smoothing control using supercapacitors," IEEE Transactions, 2012.

[10] Y. Errami, M. Maaroufi, M. Ouassaid, "Modelling and Control Strategy of PMSG Based Variable Speed Wind Energy Conversion System," IEEE Transactions, 2010

[11] G. Poddar, A. Joseph, and A.K. Unnikrishnan, "Sensorless Variable-Speed Controller for Existing Fixed-Speed Wind Power Generator With Unity-Power-Factor Operation," IEEE Trans.Ind. Electron, vol. 50, pp. 1007-1015, Oct. 2003.

[12] Y. Weizheng, K. Woo, Z. Ruijie, G. Wei, and W. Yue, "Analyze of current control strategy based on vector Control for Permanent-Magnet Synchronous Generator in Wind Power System," Power Electronics and Motion Control Conference, 2009. IPEMC '09. IEEE 6th International, pp. 2209-2212, May 2009.

[13] A. Ansel , B. Robyns, "Modelling and simulation of an autonomous variable speed micro hydropower station," Mathematics and Computers in Simulation, no. 71, pp. 320332, 2006.

[14] Y. Liyong, Y. Peie, C. Zhenguo, C. Zhigang, L. Zhengxi, "A Novel Control Strategy of Power Converter Used To Direct Driven Permanent Magnet Wind Power Generation System," IEEE Power Electronics and Intelligent Transportation System (PEITS), $2^{\text {nd }}$ International Conference vol. 1, pp. 456-459, Dec. 2009

[15] M. Mansour, M.N. Mansouri and M.F. Mimouni, "Study and Control of a Variable-Speed Wind-Energy System Connected to the Grid," International Journal Of Renewable Energy Research, IJRER, Vol.1, No.2, pp.96104, 2011.

[16] B. Lu, S.K. Sharma, "A literature review of IGBT fault diagnostic and protection methods for power inverters," IEEE Transactions on Industry Applications 2009; 45(5): $1770-7$

[17] M. Trabelsi, M. Boussak, M. Gossa, "PWM-Switching pattern-based diagnosis scheme for single and multiple open-switch damages in VSI-fed induction motor drives," ISA Transactions 2012, 333-444.

[18] S. Bolognani, M. Zordani, M. Zigliotto, "Experimental fault-tolerant control of a PMSM drive," IEEE trans, 2000, IE-4, (5), pp. 1134-1141.

[19] K.-H. Kim, D.-U. Choi, B.-G. Gu, I.-S. Jung "Fault model and performance evaluation of an inverter-fed permanent magnet synchronous motor under winding shorted turn and inverter switch open", Electric Power Applications,IET, volume 4, issue 4, April 2010. 